UDC 546.26:661.183

Wipsar Sunu Brams Dwandaru ${ }^{a}$, Emi Kurnia Sari ${ }^{a}$, Wira Widyawidura ${ }^{b}$, Deni Shidqi Khaerudini ${ }^{c}$, Elisabeth Pratidhina ${ }^{a}$, Mela Agustin ${ }^{a}$, Linda Purnamasari ${ }^{a}$, Wiwin Silfiyani ${ }^{a}$, Tria Andriana Yongga ${ }^{a}$

\title{
CARBON NANODOTS FROM WATERMELON PEEL AS CO, ABSORBENTS IN BIOGAS
}

\author{
a Physics Education Department, Faculty of Mathematics and Natural Sciences, \\ Universitas Negeri Yogyakarta, Indonesia \\ b Mechanical Engineering, Faculty of Engineering, Universitas Proklamasi, Yogyakarta, Indonesia \\ ${ }^{\mathrm{c}}$ Research Center for Physics, Indonesian Institute of Science, Banten, Indonesia
}

\begin{abstract}
We report the synthesis of carbon nanodots (Cdots) from watermelon peel waste. The Cdots obtained were characterized using ultraviolet-visible, photoluminescence, Fouriertransform infrared spectroscopies, and transmission electron microscopy. The Cdots exhibited green luminescence. The average diameter of the Cdots was $4 \mathrm{~nm}$ and the $\mathrm{C}=\mathrm{C}$ functional groups were dominant. The Cdots were then utilized as $\mathrm{CO}_{2}$ absorbent in biogas. The result showed that the concentration of $\mathrm{CO}_{2}$ was reduced by up to $40 \%$ based on the gas chromatography test. The higher the Cdots concentration, the higher is the amount of $\mathrm{CO}_{2}$ that can be reduced in the biogas. Based on the heat performance test, higher concentration of Cdots produced higher heat energy of the biogas.
\end{abstract}

Keywords: carbon nanodots, watermelon peel waste, $\mathrm{CO}_{2}$ absorbent, biogas, heat energy.

DOI: $10.32434 / 0321-4095-2021-137-4-41-49$

\section{Introduction}

Biogas is one of the renewable alternative energies that is being intensively developed and has been widely studied for its use to substitute natural gas in recent years. Biogas has an important role in the development of renewable energy, and it is estimated that the use of biogas in the world will be doubled from 14.5 gigawatts in 2012 to 29.5 gigawatts in 2022 [1]. Biogas is produced from organic materials through anaerobic fermentation process. Organic materials used in this process are vegetable, fruit, organic, and livestock manure. Biogas development in Indonesia is quite prospective considering its large amount of organic materials and livestock.

Biogas consists of methane $\left(\mathrm{CH}_{4}\right.$, around 50$70 \%)$, carbon dioxide $\left(\mathrm{CO}_{2}, 30-50 \%\right)$, and other residual gas compounds [2]. The energy contained in the biogas depends on the concentration of $\mathrm{CH}_{4}$. The higher the concentration of $\mathrm{CH}_{4}$, the greater is the energy of the biogas. $\mathrm{CO}_{2}$ is an unwanted gas because it can disrupt the combustion process and affect the heating value [3]. The higher the concentration of $\mathrm{CO}_{2}$, the lower is the calorific value of the biogas. Therefore, the $\mathrm{CO}_{2}$ must be removed through the biogas purification process. Absorption is the simplest and easiest method in biogas purification. In previous study [4], activated carbon and zeolite are used as absorbent materials in biogas purification due to their suitable pore sizes. The pore size of activated carbon and zeolite are less than $2 \mathrm{~nm}$ [5] and $1 \mathrm{~nm}$ [4], respectively. The pores can absorb $\mathrm{CO}_{2}(0.33 \mathrm{~nm})$ and $\mathrm{H}_{2} \mathrm{~S}$ in the biogas. In this study, we use carbon nanodots (Cdots) as $\mathrm{CO}_{2}$ absorbent in biogas.

Cdots are 0-dimensional (0D) novel carbon material with sizes of less than $10 \mathrm{~nm}$. After their discovery in 2004, Cdots attracted much attention because they have several superior properties, including nanoscale diameter, low toxicity, biocompatibility [6], photoluminescence, water solubility, and excellent stability [7]. Cdots consist of core and surface state. The core of Cdots is constructed from hexagonal $\mathrm{C}=\mathrm{C}$ (double bond) carbon chains. The surface state of the Cdots may consist of hydroxyl groups, which bonded to the core. Cdots have been applied in various fields, such as sensors, optoelectronic devices [6], drug delivery,

(C) W.S.B. Dwandaru, E.K. Sari, W. Widyawidura, D.S. Khaerudini, E. Pratidhina, M. Agustin, L. Purnamasari, W. Silfiyani, T.A. Yongga, 2021 
bioimaging [8], gene delivery [9], and energy harvesting [10]. Although having many applications, the Cdots has not been used as $\mathrm{CO}_{2}$ absorbent in the biogas purification.

The properties of Cdots can be adjusted by modifying their chemical composition. To date, many studies have been carried out to synthesize Cdots with chemical, electrochemical or physical techniques using various methods, including microwave, hydrothermal, solvothermal, thermolysis, laser ablation and electrochemical oxidation [11]. The essential ingredients of preparing Cdots are very abundant and easily found in the surrounding environment. One of them is watermelon peel waste.

The consumption of watermelon fruit in Indonesia grows $6.14 \%$ from 2014 to 2018 [12] and increasing by the year. This consumption produces abundant watermelon peel wastes. These wastes are usually just thrown away, hence creating environmental problems although they are organic materials that are degradable. To reduce and reuse the watermelon peel wastes, we use them as a precursor for Cdots material, which is then applied in the biogas purification.

\section{Experimental}

Cdots synthesis

For the sample preparation, $100 \mathrm{~g}$ of watermelon peel waste was heated in an electric oven (Mitseda) at the temperature of $250^{\circ} \mathrm{C}$ for 40 minutes until it became carbon charcoal. The charcoal was mechanically crushed into powder. The powder was filtered by using mesh sandpaper to get homogeneous powder. We made two samples with different concentrations. The first sample was obtained by dissolving $1 \mathrm{~g}$ of carbon powder in $100 \mathrm{~mL}$ of distilled water. The mixture was shaken until it was evenly mixed and then filtered using a filtering paper to remove the sediment. The obtained solution sample was the Cdots with the precursor concentration of $0.01 \mathrm{~g} \mathrm{~mL}^{-1}$. Through the same steps, the second sample was obtained from $2 \mathrm{~g}$ of carbon powder and $100 \mathrm{~mL}$ of distilled water. The second sample was called the Cdots with a precursor concentration of $0.02 \mathrm{~g} \mathrm{~mL}^{-1}$.

\section{Characterization of Cdots}

The morphology and size of the Cdots were investigated using transmission electron microscope (TEM, FEI Tecnai F20) with operating voltage of $200 \mathrm{kV}$. Fourier transform infrared spectroscopy (FT-IR, Thermo Nicolet Avatar 360 IR) characterization was performed to determine the functional groups of the Cdots. The optical properties of Cdots were investigated through the ultravioletvisible (UV-Vis) absorption and photoluminescence
(PL) spectra. The UV-Vis absorption characterization was carried out using Shimadzu UV-Vis 2450 with medium scan speed, slit width of $2.0 \mathrm{~nm}$, and wavelength range of $200 \mathrm{~nm}$ to $800 \mathrm{~nm}$. The PL properties were investigated using self-assembled PL apparatus, which consisted of two main components, i.e. Ocean Optics USB 4000 Fiber Optic Spectrometer and an excitation laser with wavelength of $405 \mathrm{~nm}$. The laser beam was passed through the sample, and then the emitted light from the sample is detected by the spectrometer.

\section{Cdots as $\mathrm{CO}_{2}$ absorbent in biogas}

In this study, the application of Cdots as $\mathrm{CO}_{2}$ absorbent was investigated. The experiment was carried out on a self-assembled biogas purifier apparatus shown in Fig. 1. The Cdots solutions were put in the tubes of the self-assembled purifier (Fig. 1,a). The volume of each tube was $50 \mathrm{~mL}$. We used a compressor to channel the biogas to the purifier (Fig. 1,b). The biogas flowed into the tubes and interacted with the Cdots solution. The purified biogas was then collected in a container (Fig. 1,c).

\section{Characterization of biogas}

The biogas was characterized using gas chromatography (GC) and heat performance tests. The concentrations of $\mathrm{CH}_{4}$ and $\mathrm{CO}_{2}$ gases in the biogas before and after the purification process were measured using GC Shimadzu 14A. Moreover, the purified biogas was subjected to a heat performance test (Fig. 2) to determine the quality of the biogas after purification. The purified biogas was channeled to a gas stove. The stove was used to boil $1 \mathrm{~kg}$ of water; thus, the temperature of the water increased. Based on the temperature difference, the heat energy (Q) can be calculated using the following equation:

$\mathrm{Q}=\mathrm{m} \cdot \mathrm{c} \cdot \Delta \mathrm{t}$,

where $\mathrm{m}, \mathrm{c}$, and $\Delta \mathrm{t}$ represented mass, the specific heat of water $\left(1000 \mathrm{cal} / \mathrm{kg}^{0} \mathrm{C}\right)$ and temperature difference, respectively.

\section{Results and discussion}

The preparation of Cdots solutions from watermelon waste via heating in the oven yields solutions with brown color. As the precursor concentration increases, the solution becomes darker (Fig. 3). The higher precursor concentration indicates the more Cdots particles are formed [13]. As shown in Fig. 3,c and 3,d, a simple test is conducted to identify the optical property of the Cdots solution by exposing it with UV/violet laser $(405 \mathrm{~nm}, 5 \mathrm{~mW})$. The Cdots solution emits green luminescence. The sample solution with greater precursor concentration emits higher intensity. The samples are then

W.S.B. Dwandaru, E.K. Sari, W. Widyawidura, D.S. Khaerudini, E. Pratidhina, M. Agustin, 


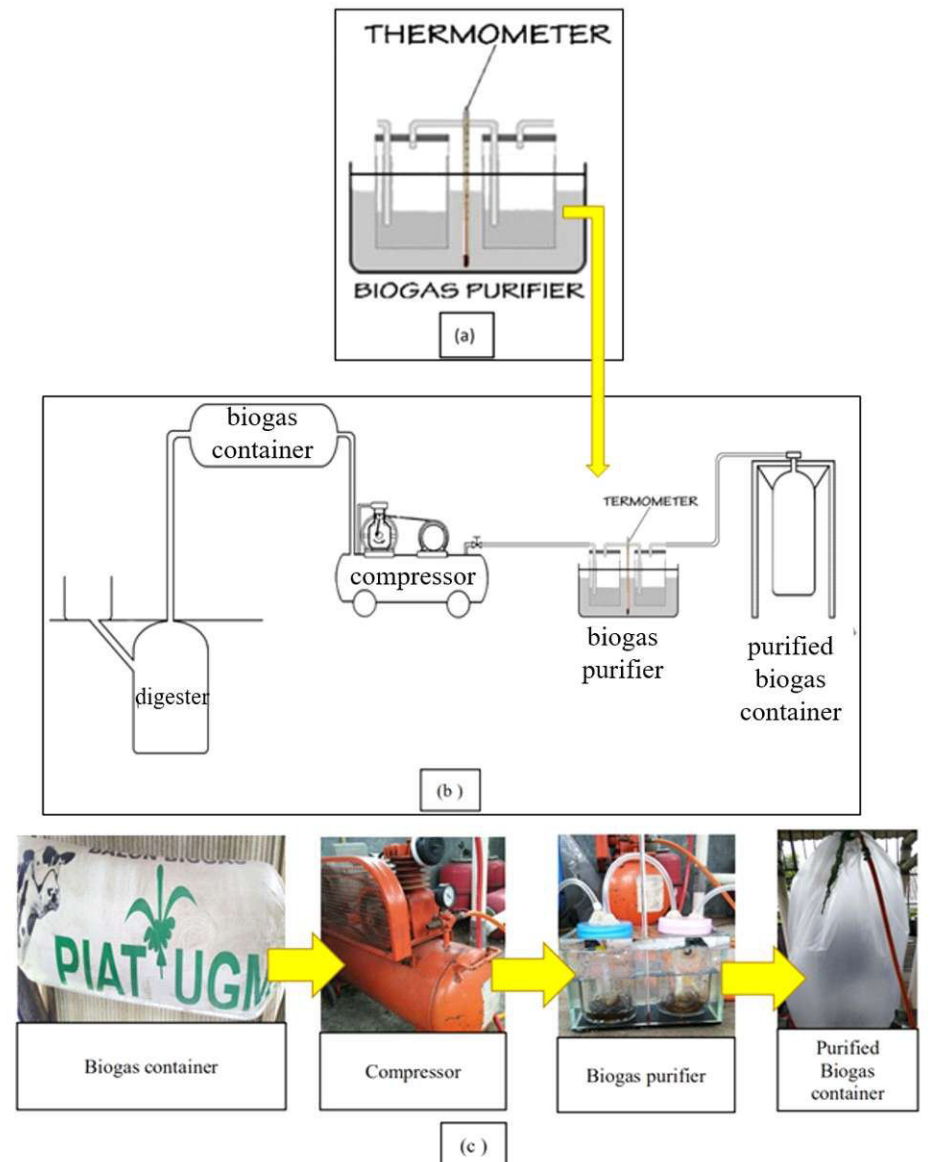

Fig. 1. The biogas purification process: (a) the purifier tube, (b) the scheme of biogas purification and (c) purification procedure
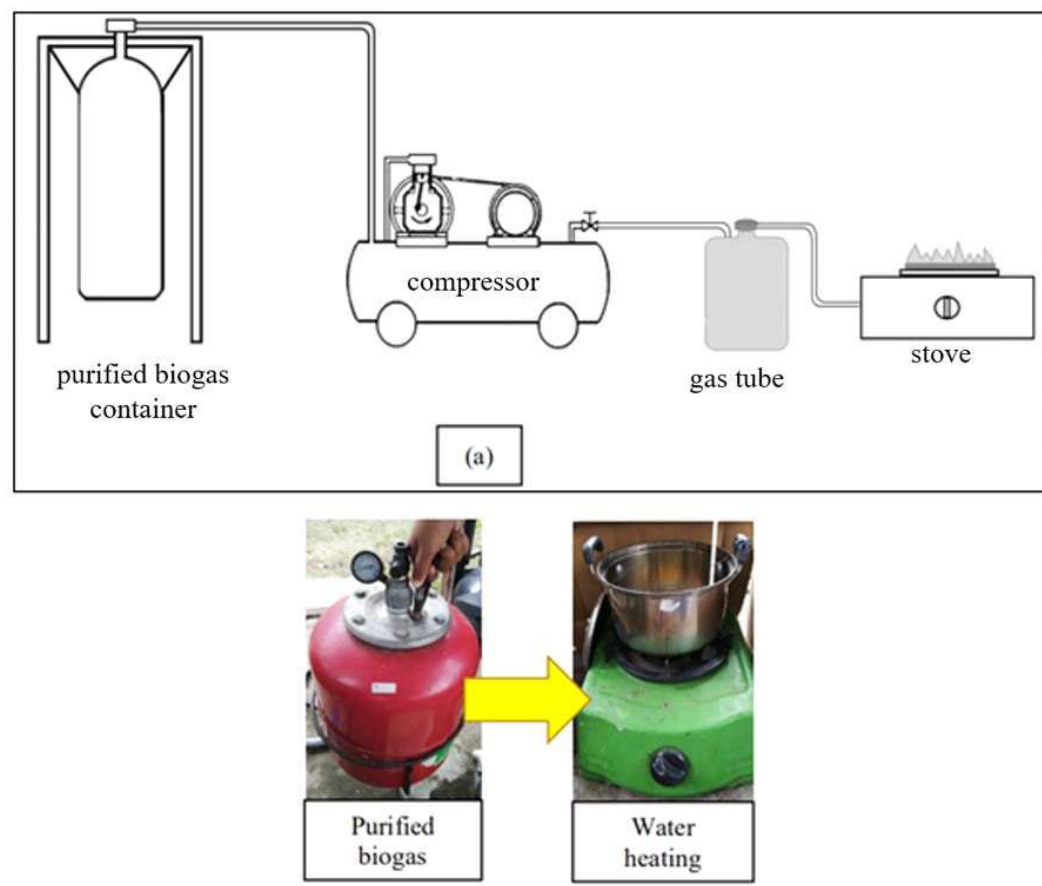

(b)

Fig. 2. Heat performance test process: (a) the apparatus for heat performance test and (b) the heat performance test procedure 


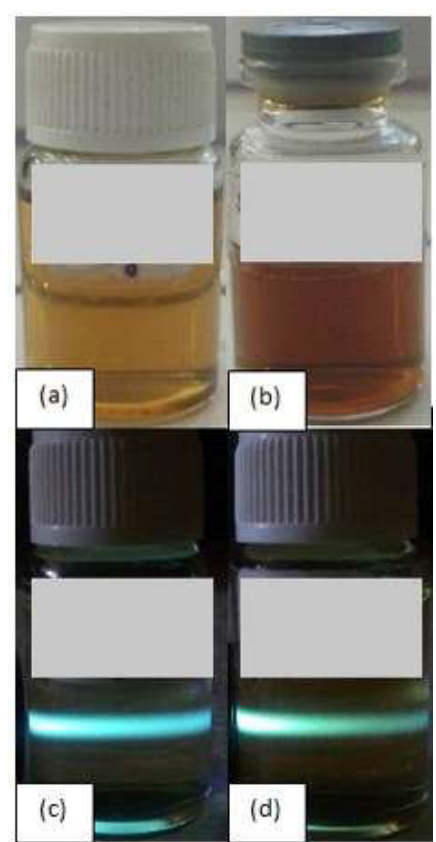

Fig. 3. Cdots solution with precursor concentrations of

(a) $0.01 \mathrm{~g} \mathrm{~mL}^{-1}$, (b) $0.02 \mathrm{~g} \mathrm{~mL}^{-1}$, (c) $0.01 \mathrm{~g} \mathrm{~mL}^{-1}$ and (d) $0.02 \mathrm{~g} \mathrm{~mL}^{-1}$ irradiated by UV laser

characterized using UV-Vis, PL, FT-IR and TEM.

The UV-Vis characterization shows an absorption peak and a shouldering peak at 203.5 and $252.5 \mathrm{~nm}$, respectively, for the Cdots solution with the precursor concentration of $0.01 \mathrm{~g} \mathrm{~mL}^{-1}$ (Fig. 4). Moreover, an absorption peak and a shouldering peak are observed at 202.5 and $256.5 \mathrm{~nm}$, respectively, for the Cdots solution with the precursor concentration of $0.02 \mathrm{~g} \mathrm{~mL}^{-1}$. Previous studies indicate that the absorption peak of Cdots is usually in the range of $250 \mathrm{~nm}$ to $305 \mathrm{~nm}$ as given, e.g. in ref. [14]. Both Cdots solutions show absorbance peaks at around $250 \mathrm{~nm}$; those peaks are attributed to the

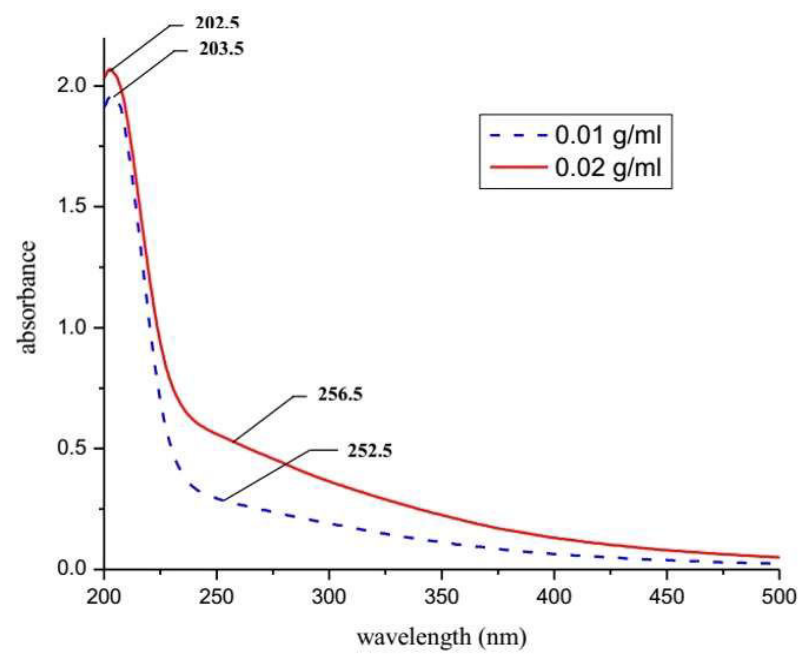

Fig. 4. UV-Vis spectra of Cdots samples $\pi-\pi^{*}$ transition of $\mathrm{C}=\mathrm{C}$ bonds at the Cdots' core. On the other hand, the UV-Vis spectra do not indicate the absorption peak due to the surface state of the Cdots. The prepared Cdots may only consist of a small number of surface states.

The PL spectra of the Cdots solutions at an excitation wavelength of $405 \mathrm{~nm}$ are presented in Fig. 5. For each precursor concentration variation, the PL peak is obtained at a wavelength of around $499 \mathrm{~nm}$. This wavelength belongs to the spectrum of green light $(495 \mathrm{~nm}-570 \mathrm{~nm})$; thus, the Cdots emit green luminescence under UV light exposure consistent with the results shown in Fig. 3. The PL spectra also show that the emitted light intensity is higher for the Cdots with higher precursor concentration. This is due to more particles that are excited at higher precursor concentration. However, the PL test, which is self-assembled, has a limitation that is producing a broad intensity peak.

Figure 6 displays the FT-IR spectra of the Cdots solutions. The FT-IR spectra for two different precursor concentrations of Cdots are similar. The IR spectrum of Cdots for precursor concentration of $0.01 \mathrm{mg} \mathrm{L}^{-1}\left(0.02 \mathrm{mg} \mathrm{L}^{-1}\right)$ has bands at $1633.60 \mathrm{~cm}^{-1}$ $\left(1639.63 \mathrm{~cm}^{-1}\right)$ and $3444.13 \mathrm{~cm}^{-1}\left(3438.74 \mathrm{~cm}^{-1}\right)$, which corresponds to $\mathrm{C}=\mathrm{C}$ and $\mathrm{O}-\mathrm{H}$ functional groups, respectively. The $\mathrm{C}=\mathrm{C}\left(\mathrm{sp}^{2}\right)$ functional group verify the Cdots' core structure. The core structure confirms that the origin of the UV-Vis absorption peak at $252(256 \mathrm{~nm})$ is related to the $\pi-\pi^{*}$ transition, which corresponds to electron transition in $\mathrm{sp}^{2}$ hybridized orbitals. Meanwhile, the hydroxyl $(\mathrm{O}-\mathrm{H})$ functional groups may come from the distilled water or the surface state of the Cdots. However, there is no indication of the surface state from the $\mathrm{UV}-\mathrm{Vis}$ spectra. Hence, the $\mathrm{O}-\mathrm{H}$ functional groups

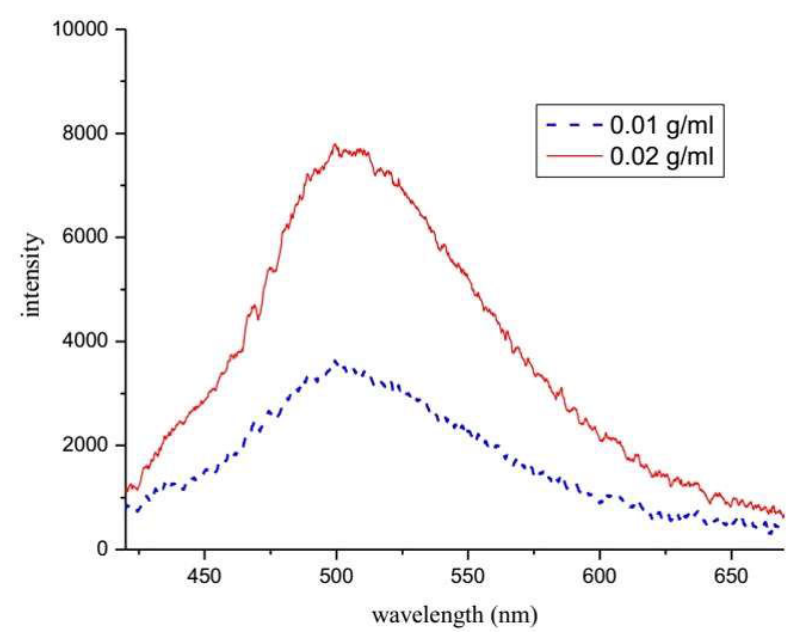

Fig. 5. PL spectra of Cdots samples under an excitation wavelength of $405 \mathrm{~nm}$

W.S.B. Dwandaru, E.K. Sari, W. Widyawidura, D.S. Khaerudini, E. Pratidhina, M. Agustin,

L. Purnamasari, W. Silfiyani, T.A. Yongga 


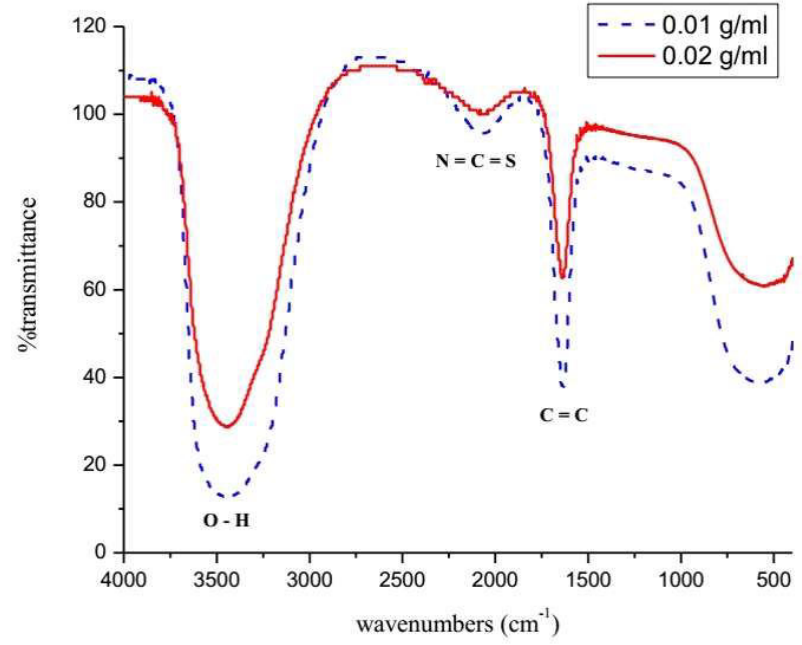

Fig. 6. FT-IR bands of the Cdots samples more likely come from the distilled water molecule. This is in accordance with the FT-IR result obtained in ref. [15]. Apart from the main bands, there is a weak band for Cdots with precursor concentration of $0.01 \mathrm{mg} \mathrm{L}^{-1}\left(0.02 \mathrm{mg} \mathrm{L}^{-1}\right)$ at $2088.11 \mathrm{~cm}^{-1}$ $\left(2098.27 \mathrm{~cm}^{-1}\right)$, which may correspond to $\mathrm{N}=\mathrm{C}=\mathrm{S}$ functional group. This functional group may come from the watermelon peel waste.

The morphology and size of the prepared Cdots are studied using TEM imaging. As shown in Fig. 7,a, a ring-shaped electron diffraction pattern is produced carbon dots indicating that the Cdots have an amorphous structure. The Cdots are sphere-shaped and homogenously dispersed as shown in Fig. 7,b. The TEM image (Fig. 7,b) shows a large background under the Cdots which might be due to the overlapping of some Cdots. A thick sample may cause
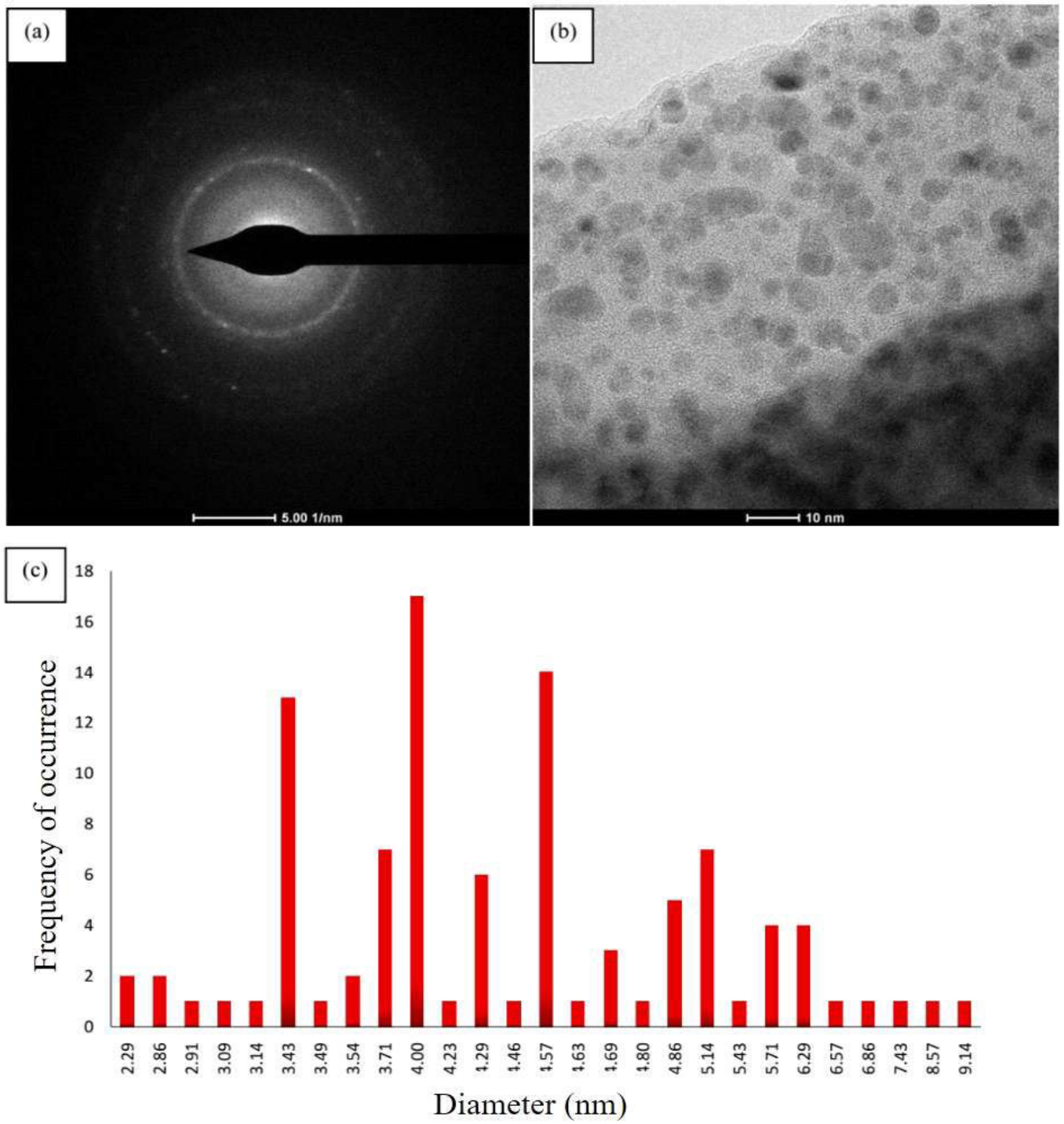

Fig. 7. TEM analysis results: (a) diffraction pattern of Cdots, (b) morphology and (c) diameter distribution of the Cdots 
overlapping of some Cdots and produce a darker TEM image. Figure 7,c shows the distribution of Cdots sizes which is close to a Gaussian distribution. The distribution shows that the average diameter of the prepared Cdots is $4.00 \mathrm{~nm}$ with more than 100 Cdots are counted.

We further study the use of the Cdots prepared from watermelon peel wastes for biogas purification. Biogas consists of several gases; among them, $\mathrm{CH}_{4}$ and $\mathrm{CO}_{2}$ are dominant. The amount of energy produced by the biogas depends on the concentration of $\mathrm{CH}_{4}$. On the other hand, $\mathrm{CO}_{2}$ is an unwanted gas because it can disrupt the combustion process. Hence, to improve the quality of biogas, the concentration of $\mathrm{CO}_{2}$ needs to be decreased. The size of $\mathrm{CO}_{2}$ molecule is $0.33 \mathrm{~nm}$. Meanwhile, Cdots have a core that consists of the hexagonal carbon chain $(\mathrm{C}=\mathrm{C})$ with a diameter of $2.8 \mathrm{~nm}$. In the Cdots solution, the core may be overlapping and form nets. Because of the smaller size of $\mathrm{CO}_{2}$ molecules, they are potentially trapped on the nets, and thus the concentration of $\mathrm{CO}_{2}$ in the biogas can be reduced. The higher the concentration of the Cdots, the higher is the number of nets contained in the Cdots.

We investigate the properties of the biogas before and after the purification process through GC and heat performance tests. The GC analysis gives the $\mathrm{CH}_{4}$ and $\mathrm{CO}_{2}$ compositions of biogas before and after the purification process (Fig. 8). Figure 8,a shows the concentration of $\mathrm{CO}_{2}$ (red bar) and $\mathrm{CH}_{4}$ (blue bar) gases before purification. The concentration of $\mathrm{CO}_{2}$ gas is about $15 \%$ higher than the concentration of $\mathrm{CH}_{4}$ gas. Figure 8 ,b shows the concentration of $\mathrm{CO}_{2}$ (red bar) and $\mathrm{CH}_{4}$ (blue bar) gases after the purification process. After the purification process, the concentration of $\mathrm{CH}_{4}$

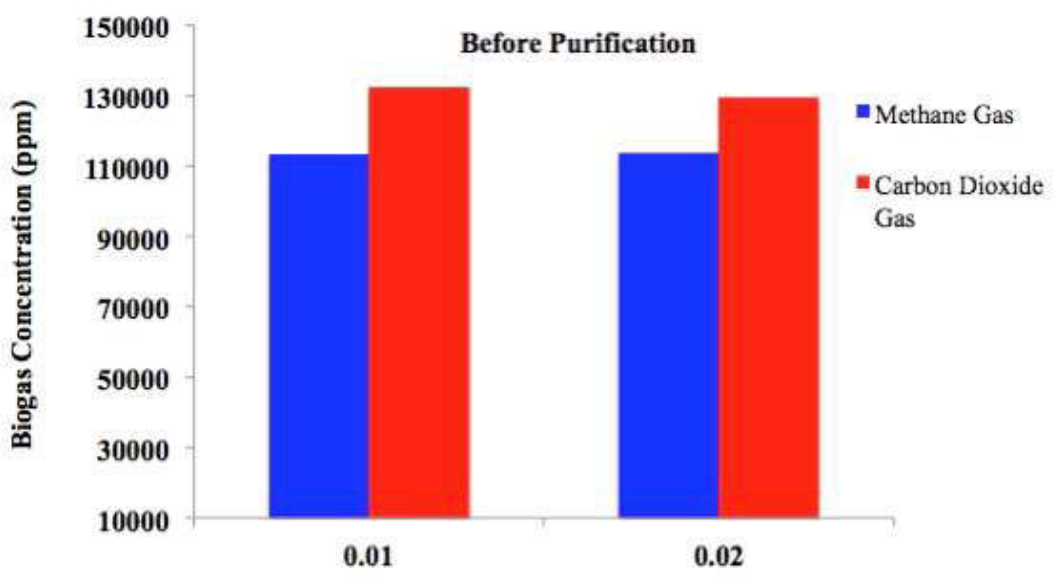

(a) Precursor Concentration of Cdots $(\mathrm{g} / \mathrm{mL})$

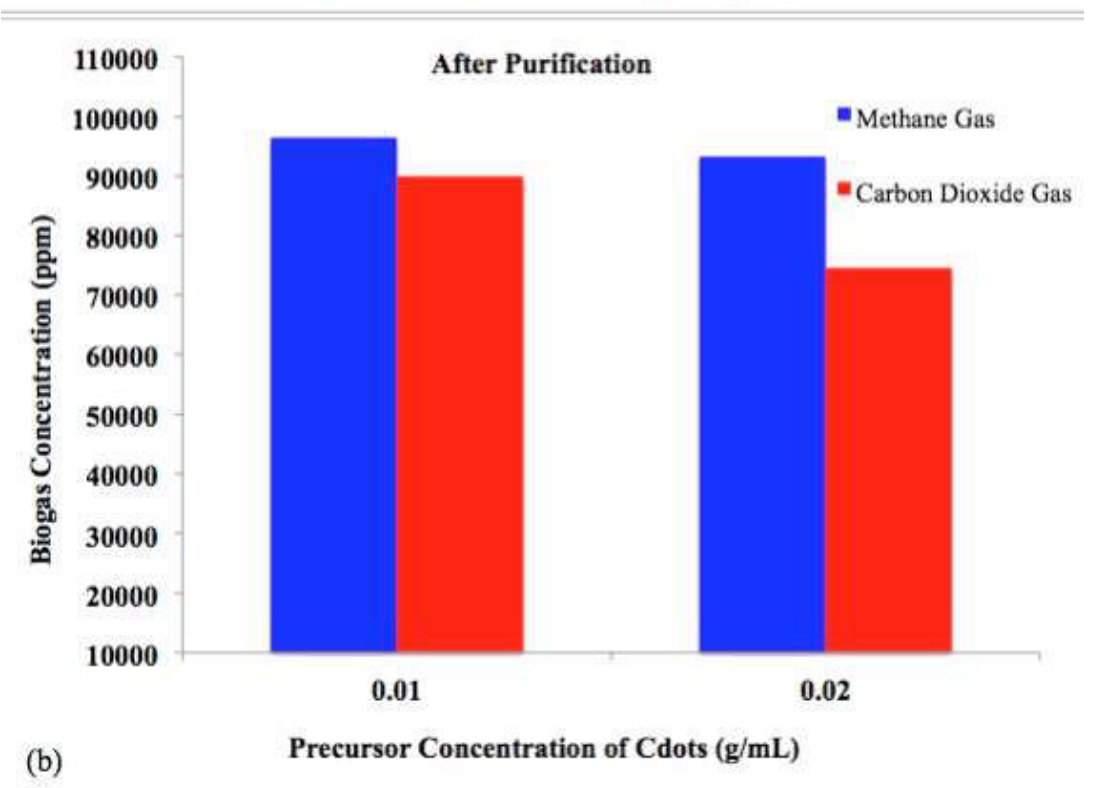

Fig. 8. GC characterization results (a) before and (b) after the purification process

W.S.B. Dwandaru, E.K. Sari, W. Widyawidura, D.S. Khaerudini, E. Pratidhina, M. Agustin, 
becomes higher than the concentration of $\mathrm{CO}_{2}$. The concentration of $\mathrm{CO}_{2}$ reduces by $32 \%$ and $42 \%$ after purification using Cdots solution with precursor concentrations of 0.01 and $0.02 \mathrm{~g} \mathrm{~mL}^{-1}$, respectively. This indicates that a higher precursor concentration of Cdots solution absorbs more $\mathrm{CO}_{2}$ gas. Unfortunately, the concentration of $\mathrm{CH}_{4}$ also reduces by $14 \%$ and $17 \%$ after purification involving Cdots solutions with precursor concentrations of 0.01 and $0.02 \mathrm{~g} \mathrm{~mL}^{-1}$, respectively. It means that using Cdots as a biogas purifier has an advantage in reducing the amount of $\mathrm{CO}_{2}$ but it also has a disadvantage because it reduces the $\mathrm{CH}_{4}$ gas (in a small amount).

The biogas purification process using Cdots is successful in reducing the $\mathrm{CO}_{2}$ gas until it becomes lower than the concentration of $\mathrm{CH}_{4}$ gas. However, the $\mathrm{CO}_{2}$ concentration is still only about $7 \%$ and $20 \%$ lower than the $\mathrm{CH}_{4}$ concentration after purification involving Cdots with precursor concentrations of 0.01 and $0.02 \mathrm{~g} \mathrm{~mL}^{-1}$, respectively. There are two factors that may contribute to this result. First, the size of $\mathrm{CH}_{4}$ molecule is $0.38 \mathrm{~nm}$, which is only slightly larger than that of $\mathrm{CO}_{2}$ molecule. Thus, the nets in the Cdots can trap not only $\mathrm{CO}_{2}$ molecule but also $\mathrm{CH}_{4}$ molecule, which cause a decrease in the $\mathrm{CH}_{4}$ gas concentration. Second, the trapped $\mathrm{CO}_{2}$ molecule on the Cdots nets may be released due to the continuous gas pressure during the purification process. This causes the final concentration of $\mathrm{CO}_{2}$ gas in the biogas sample cannot be reduced in a more significant amount.

A heat performance test is also conducted on the biogas purified by the Cdots solutions. Figure 9,a shows the heat energy of biogas after the purification process with various concentrations of the Cdots. The heat energies produced by the biogas samples, which are purified by Cdots with precursor concentrations of $0.01 \mathrm{~g} \mathrm{~mL}^{-1}$ and $0.02 \mathrm{~g} \mathrm{~mL}^{-1}$ are 21,000 and 34,000 calories, respectively. The result indicates that the biogas purified with higher precursor concentration of Cdots produces higher heat energy. The reduction in $\mathrm{CO}_{2}$ concentration improves the efficiency of biogas because less $\mathrm{CO}_{2}$ gas disrupts the combustion process. Qualitatively, we can compare the efficiency of the biogas samples by observing the fire texture produced in the combustion process (Fig. 9,b and 9,c). The biogas purified by Cdots with the precursor concentration of $0.02 \mathrm{~g} \mathrm{~mL}^{-1}$ produces a bigger and more bluish flame as compared with the biogas purified by Cdots with a precursor concentration of $0.01 \mathrm{~g} \mathrm{~mL}^{-1}$. The blue color flame produced indicates that the biogas sample is rich in $\mathrm{CH}_{4}$ molecule.

\section{Conclusions}

In summary, we have prepared Cdots from

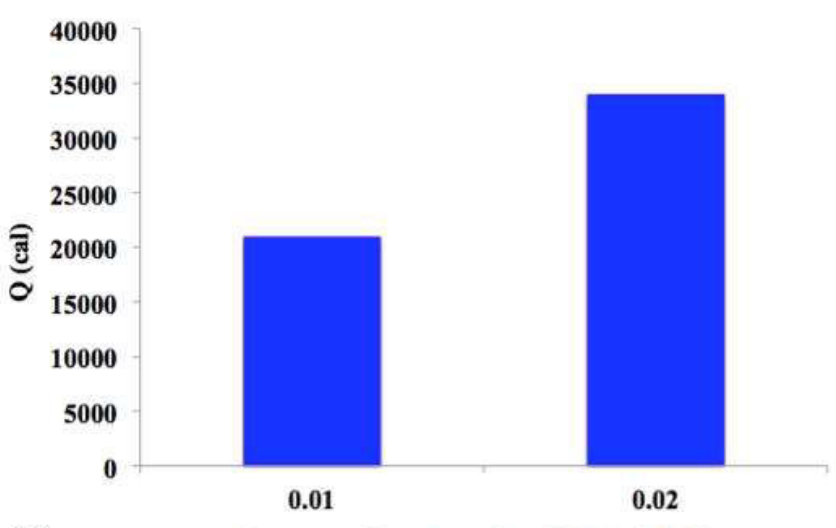

(a) Precursor Concentration of Cdots $(\mathrm{g} / \mathrm{mL})$

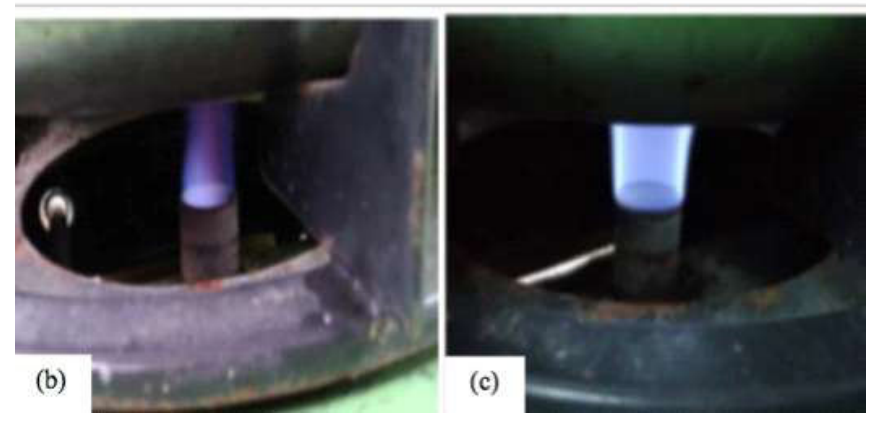

Fig. 9. (a) - Heat performance test; fire texture of biogas from Cdots purification with precursor concentrations of $0.01 \mathrm{~g} \mathrm{~mL}^{-1}$ (b) and $0.02 \mathrm{~g} \mathrm{~mL}^{-1}(\mathrm{c})$ 
watermelon peel waste using the heating method in an oven. According to the TEM image, the size of the prepared Cdots is $4.0 \mathrm{~nm}$ and carbon dots emit intense green luminescence at $499 \mathrm{~nm}$. The FT-IR spectroscopy indicates the presence of $\mathrm{C}=\mathrm{C}, \mathrm{O}-\mathrm{H}$, and $\mathrm{N}=\mathrm{C}=\mathrm{S}$ functional groups in the Cdots. Moreover, the Cdots as a $\mathrm{CO}_{2}$ absorbent in the biogas purification has been explored. Cdots showed a potential ability to absorb $\mathrm{CO}_{2}$ in biogas. Hexagonal carbon chain in the core of Cdots may form nets, which can trap $\mathrm{CO}_{2}$ molecule. The higher the concentration of the Cdots, the more $\mathrm{CO}_{2}$ can be reduced in the biogas, e.g. in this case is reduced by up to $40 \%$. The biogas that is purified with a higher precursor concentration produces higher heat energy. However, the concentration of $\mathrm{CH}_{4}$ is also reduced due to the purification. This study is still limited to Cdots in a liquid phase and the purification process is only conducted once. Further research is needed to improve the Cdots performance as a $\mathrm{CO}_{2}$ absorbent in the biogas purification. Moreover, it is also interesting to determine the yield of the Cdots in order to obtain the appropriate amount of watermelon peel needed to produce the Cdots material for the biogas purification.

\section{Acknowledgements}

The authors would like to thank the Faculty of Mathematics and Natural Science, Universitas Negeri Yogyakarta for supporting this study. The authors would also like to give gratitude to the Indonesian Institute of Science for the generosity of using their facilities to conduct this study.

\section{REFERENCES}

1. Biogas as a renewable energy fuel - a review of biogas upgrading, utilisation and storage / Khan I.U., Othman M.H.D., Hashim H., Matsuura T., Ismail A.F., Rezaei-DashtArzhandi M., Azelee I.W. // Energy Convers. Manage. - 2017. - Vol.150. P.277-294.

2. Wijffels R.H., Barbosa M.J., Eppink M.H.M. Microalgae for the production of bulk chemicals and biofuels // Biofuels Bioprod. Bioref. - 2010. - Vol.4. - No. 3. - P.287-295.

3. Sheng C., Azevedo J.L.T. Estimating the higher heating value of biomass fuels from basic analysis data // Biomass Bioenergy. - 2005. - Vol.28. - No. 5. - P.499-507.

4. Comparative studies on the kinetics of biogas purification using activated carbon and zeolite / Abdullahi A., Alhassan M., Isah A.G., Sani K.A., Olalekan O.A. // IOP Conf. Ser. Earth Environ. Sci. - 2008. - Vol.173. - Art. No. 012046.
5. Removal of hydrogen sulfide from a biogas mimic by using impregnated activated carbon adsorbent / Zulkefli N.N., Masdar M.S., Wan Isahak W.N.R., Jahim J.M., Rejab S.A.M., Chien L.C. // PLoS One. - 2019. - Vol.14. - No. 2. - Art. No. $\mathrm{e} 0211713$.

6. Simple and green synthesis of nitrogen-, sulfur-, and phosphorus-co-doped carbon dots with tunable luminescence properties and sensing application / Wang C., Sun D., Zhuo K., Zhang H., Wang J. // RSC Adv. - 2014. - Vol.4. - No. 96. P.54060-54065.

7. Wang C., Xu Z., Zhang C. Polyethyleneiminefunctionalized fluorescent carbon dots: water stability, $\mathrm{pH}$ sensing, and cellular imaging // ChemNanoMat. - 2015. - Vol.1. No. 2. - P.122-127.

8. Hollow luminescent carbon dotsfor drug delivery / Wang Q., Huang X., Long Y., Wang X., Zhang H., Zhu R., Liang L., Teng P., Zheng H. // Carbon. - 2013. - Vol.59. P.192-199.

9. Nano-carrier for gene delivery and bioimaging based on carbon dots with PEI-passivation enhanced fluorescence / Liu C., Zhang P., Zhai X., Tian F., Li W., Yang J., Liu Y., Wang H., Wang W., Liu W. // Biomaterials. - 2012. - Vol.33. - No. 13. P.3604-3613.

10. Narayanan R., Deepa M., Srivastava A.K. Forster resonance energy transfer and carbon dots enhance light harvesting in a solid-state quantum dot solar cell // J. Mater. Chem. A. 2013. - Vol.1. - No. 12. - P.3907-3918.

11. Das R., Bandyopadhyay R., Pramanik P. Carbon quantum dots from natural resource: a review // Mater. Today Chem. - 2018. - Vol.8. - P.96-109.

12. Partial characterization of watermelon albedo pectin extracted using citric acid combined with microwave assisted extraction / Ishartani D., Sari A.M., Arifani R., Kawiji // IOP Conf. Ser. Earth Environ. Sci. - 2020. - Vol.518. - Art. No. 012060 .

13. Optical properties comparison of carbon nanodots synthesized from commercial granulated sugar using hydrothermal method and microwave / Dwandaru W.S.B., Bilqis S.M., Wisnuwijaya R.I., Isnaeni // Mater. Res. Express. - 2019. Vol.6. - Art. No. 105041.

14. A facile and green approach to prepare carbon dots with $\mathrm{pH}$-dependent fluorescence for patterning and bioimaging / Guo X., Zhu Y., Zhou L., Zhang L., You Y., Zhang H., Hao J. // RSC Adv. - 2018. - Vol.8. - P.38091-38099.

15. Lewa I.W.L., Isnaeni Enhancing sensitivity of carbon dots as Fe ion sensor using time-resolved photoluminescence technique // J. Nanopart. Res. - 2020. - Vol.22. - Art. No. 252.

Received 23.03.2021

W.S.B. Dwandaru, E.K. Sari, W. Widyawidura, D.S. Khaerudini, E. Pratidhina, M. Agustin, L. Purnamasari, W. Silfiyani, T.A. Yongga 


\section{ВУГЛЕЦЕВІ НАНОТОЧКИ З ЛУШПАЙКИ КАВУНА ЯК АБСОРБЕНТИ СО 2 У БІОГАЗІ}

В.С.Б. Двандару, Е.К. Сарі, В. Відявідура, Д.С. Хаерудіні, Е. Пратідхіна, М. Агустін, Л. Пурнамасарі, В. Сільфіяні, T.A. Йонгга

У роботі описано синтез вуглецевих наноточок 3 відходів лушпайок кавуна. Одержані вуглецеві наноточки були охарактеризовані з використанням методів УФ-, видимої, фотолюмінісцентної, інфрачервоної з Фур'є-перетворенням спектроскопій, а також трансмісійної електронної мікроскопії. Вуглецеві наноточки проявляли люмінесценцію у зеленому діапазоні видимого випромінювання. Середній діаметр вуглецевих наноточок був 4 нм і $\mathrm{C}=\mathrm{C}$ функціональні групи були домінуючими. Вуглецеві наноточки були використані як абсорбенти $\mathrm{CO}_{2}$ у біогазі. Отримані результати показали, що концентрація $\mathrm{CO}_{2}$ знижувалася до $40 \%$ (згідно $з$ хроматографічними дослідженнями). Чим вища концентрація вуглецевих наноточок, тим більша кількість $\mathrm{CO}_{2}$ може бути поглинута у біогазі. Більші концентрації вуглецевих наноточок забезпечують одержання більшої кількості теплової енергії біогазу.

Ключові слова: вуглецеві наноточки; відходи лушпайки кавуна; абсорбція $\mathrm{CO}_{2}$; біогаз; теплова енергія.

\section{CARBON NANODOTS FROM WATERMELON PEEL AS $\mathrm{CO}_{2}$ ABSORBENTS IN BIOGAS}

W.S.B. Dwandaru ${ }^{a,}{ }^{*}$, E.K. Sari ${ }^{a}$, W. Widyawidura ${ }^{b}$, D.S. Khaerudini c, E. Pratidhina a, M. Agustin a, L. Purnamasari ${ }^{a}$, W. Silfiyani ${ }^{a}$, T.A. Yongga ${ }^{a}$

a Physics Education Department, Faculty of Mathematics and Natural Sciences, Universitas Negeri Yogyakarta, Indonesia

${ }^{b}$ Mechanical Engineering, Faculty of Engineering, Universitas Proklamasi, Yogyakarta, Indonesia

c Research Center for Physics, Indonesian Institute of Science, Banten, Indonesia

\section{*e-mail: wipsarian@uny.ac.id}

We report the synthesis of carbon nanodots (Cdots) from watermelon peel waste. The Cdots obtained were characterized using ultraviolet-visible, photoluminescence, Fourier-transform infrared spectroscopies, and transmission electron microscopy. The Cdots exhibited green luminescence. The average diameter of the Cdots was $4 \mathrm{~nm}$ and the $\mathrm{C}=\mathrm{C}$ functional groups were dominant. The Cdots were then utilized as $\mathrm{CO}_{2}$ absorbent in biogas. The result showed that the concentration of $\mathrm{CO}_{2}$ was reduced by up to $40 \%$ based on the gas chromatography test. The higher the Cdots concentration, the higher is the amount of $\mathrm{CO}_{2}$ that can be reduced in the biogas. Based on the heat performance test, higher concentration of Cdots produced higher heat energy of the biogas.

Keywords: carbon nanodots; watermelon peel waste; $\mathrm{CO}_{2}$ absorbent; biogas; heat energy.

\section{REFERENCES}

1. Khan IU, Othman MH, Hashim H, Matsuura T, Ismail AF, Rezaei-DashtArzhandi M, et al. Biogas as a renewable energy fuel - a review of biogas upgrading, utilisation and storage. Energy Convers Manage. 2017; 150: 277-294.

doi: 10.1016/j.enconman.2017.08.035.

2. Wijffels RH, Barbosa MJ, Eppink MHM. Microalgae for the production of bulk chemicals and biofuels. Biofuels Bioprod Bioref. 2010; 4: 287-295. doi: 10.1002/bbb.215.

3. Sheng C, Azevedo JLT. Estimating the higher heating value of biomass fuels from basic analysis data. Biomass Bioenergy. 2005; 28: 499-507. doi: 10.1016/j.biombioe.2004.11.008.

4. Abdullahi A, Alhassan M, Isah AG, Sani KA, Olalekan OA. Comparative studies on the kinetics of biogas purification using activated carbon and zeolite. IOP Conf Ser Earth Environ Sci. 2008; 173: 012046. doi: 10.1088/1755-1315/173/1/012046.

5. Zulkefli NN, Masdar MS, Wan Isahak WNR, Jahim JM, Rejab SAM, Chien LC. Removal of hydrogen sulfide from a biogas mimic by using impregnated activated carbon adsorbent. PLoS One. 2019; 14(2): e0211713.

doi: 10.1371/journal.pone.0211713.

6. Wang C, Sun D, Zhuo K, Zhang H, Wang J. Simple and green synthesis of nitrogen-, sulfur-, and phosphorus-codoped carbon dots with tunable luminescence properties and sensing application. RSC Adv. 2014; 4: 54060-54065. doi: 10.1039/C4RA10885J.

7. Wang $\mathrm{C}, \mathrm{Xu} \mathrm{Z}$, Zhang C. Polyethyleneiminefunctionalized fluorescent carbon dots: water stability, $\mathrm{pH}$ sensing, and cellular imaging. ChemNanoMat. 2015; 1(2): 122-127. doi: 10.1002/cnma.201500009.

8. Wang Q, Huang X, Long Y, Wang X, Zhang H, Zhu R, et al. Hollow luminescent carbon dots for drug delivery. Carbon. 2013; 59: 192-199. doi: 10.1016/j.carbon.2013.03.009.

9. Liu C, Zhang P, Zhai X, Tian F, Li W, Yang J, et al. Nano-carrier for gene delivery and bioimaging based on carbon dots with PEI-passivation enhanced fluorescence. Biomaterials. 2012; 33: 3604-3613. doi: 10.1016/j.biomaterials.2012.01.052.

10. Narayanan R, Deepa M, Srivastava AK. Forster resonance energy transfer and carbon dots enhance light harvesting in a solid-state quantum dot solar cell. J Mater Chem A. 2013; 1: 3907-3918. doi: 10.1039/c3ta01601c.

11. Das R, Bandyopadhyay R, Pramanik P. Carbon quantum dots from natural resource: a review. Mater Today Chem. 2018; 8: 96-109. doi: 10.1016/j.mtchem.2018.03.003.

12. Ishartani D, Sari AM, Arifani R, Kawiji. Partial characterization of watermelon albedo pectin extracted using citric acid combined with microwave assisted extraction. IOP Conf Ser Earth Environ Sci. 2020; 518: 012060.

doi: 10.1088/1755-1315/518/1/012060.

13. Dwandaru WSB, Bilqis SM, Wisnuwijaya RI, Isnaeni. Optical properties comparison of carbon nanodots synthesized from commercial granulated sugar using hydrothermal method and microwave. Mater Res Express. 2019; 6: 105041. doi: 10.1088/2053-1591/ab3952.

14. Guo X, Zhu Y, Zhou L, Zhang L, You Y, Zhang H, et al. A facile and green approach to prepare carbon dots with $\mathrm{pH}$-dependent fluorescence for patterning and bioimaging. $R S C$ Adv. 2018; 8: 38091-38099. doi: 10.1039/C8RA07584K.

15. Lewa IWL, Isnaeni I. Enhancing sensitivity of carbon dots as $\mathrm{Fe}$ ion sensor using time-resolved photoluminescence technique. J Nanopart Res. 2020; 22: 252.

doi: 10.1007/s11051-020-04988-3. 